\title{
The Crown Witness and the Protection of Human Rights in Criminal Law Verification
}

\section{Zulfan}

Department of Law, Universitas Malikussaleh, Aceh, Indonesia

\begin{abstract}
Purpose - The purpose of this study is to show that the settings are not self-incriminating rights the right of non-self-incrimination) within the law and how the civil rights of the crown witness exist.

Design/Methodology/Approach - This prescriptive and descriptive study employs the normative legal approach and qualitative analysis.

Findings - The attorney general should prove that a criminal case is not too oriented toward witnesses, especially the crown witness, and that there is still other evidence (e.g., evidence of letters and the results of forensic analysis) and the value of convincing proof is difficult to be denied by the defendant. To avoid misinterpretation towards the presence of crown witness in a criminal case process, a regulation policy issued by the Supreme Court of Republic Indonesia is needed.
\end{abstract}

Practical Implications - Proffering a crown witness under oath is to prove that a crime opposes against the procedure of criminal law with respect the human right values.

Originality/Value - Forcing a person to prove his own guilt is an act contrary to the alleged principle of an innocent person and this research has not been published.

Keywords Crown witness, human rights, crime verification, Indonesian Criminal Procedure Code

All papers within this proceedings volume have been peer reviewed by the scientific committee of the Malikussaleh International Conference on Multidisciplinary Studies (MICoMS 2017).

\section{Introduction}

The only valid evidences according to Article 184 paragraph (1) of Kitab Undang-Undang tentang Hukum Acara Pidana (The Book of Law for Indonesian Criminal Procedure for Criminal Code) are the following:

- Witnesses.

- Expert testimony.

- Letters.

- Instructions.

- Description of the defendant.

(C) Zulfan. Published in the Emerald Reach Proceedings Series. Published by Emerald Publishing Limited. This article is published under the Creative Commons Attribution (CC BY 4.0) licence. Anyone may reproduce, distribute, translate and create derivative works of this article (for both commercial and non-commercial purposes), subject to full attribution to the original publication and authors. The full terms of this licence may be seen at http://creativecommons.org/licences/by/4.0/ legalcode

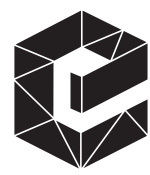

Emerald Reach Proceedings Series Vol. 1 pp. 519-524 
Proceedings of MICoMS 2017
Details can be harmonized with the contents of Article 183 Hukum Acara Pidana (Indonesian Criminal Procedure Code) which state that "Justice must not convict unless someone with at least two valid evidence he had obtained the conviction of a crime has actually occurred and that the defendant was guilty of doing it." While examining an accused at the court, the testimony of the witness is very important, and so the witness is first examined. In Article 1, paragraph 26, the Criminal Code specifies that "The witness is a person who can give information to the interests of the investigation, prosecution and judicial authorities about a criminal case that he heard him, he sees himself and his own experience." Furthermore, Article 1, paragraph 27, of Hukum Acara Pidana (Indonesian Criminal Procedure Code)mentions that "one of the evidence in a criminal case in the form of testimony from witnesses about a criminal incident that he heard him, he sees himself, his own experience with the mention that the reason of his knowledge." Then, implicitly as stipulated in Article 168 Hukum Acara Pidana (Indonesian Criminal Procedure Code) says, "... or together as the defendant ..." so that there is to know about the "crown witness." The witness was actually born, grew, and thrives in a world of criminal justice practices. The existance of this witness, if the defendant appear equally as a criminal, is separated into split sing case. Concretely, their status is as a witness against the defendant as well as other things (Mulyadi, 2003).

In practice, the judicial application of the juridical implications of the crown witness is his status as a witness on one side and his status as a defendant on the other. Thus, as a witness under oath he is obliged to provide actual information and will be valuable as evidence. Meanwhile, as the defendant then his status by the law is granted the right of badfaith, namely the right to deny the charges and challenge the testimony of the witnesses and evidence submitted at the trial. People, as crown witnesses are usually are underpressured or at least at the state of psychological pressure, therefore, we can doubt their truth. Defined and presentation of a person as a crown witness then his rights as a defendant in the position cannot be used as appropriate. This is where human rights as a crown witness is neutered and confined.

Furthermore, to have a crown witness, interesting developments from the Supreme Court of the Republic of Indonesia can be seen in the Supreme Court of the Republic of Indonesia Number 1986 K/Pid/1989 dated March 21, 1990 on behalf of Busa'i and Anwar. While on the other hand based on Supreme Court Decision No. 1174 K/Pid/1994 on behalf of Mrs. Mutiari, $\mathrm{SH}$, and the case number in the name of Bambang Wuryanto 1592K/Pid/1994 Cs, a juridical solution to the defendant as a crown witness against the other defendants is contrary to the criminal procedural law that upholds the principles of human rights and the judge should reject the crown witness.

\section{Formulation of the problem}

Based on the above background, the main problem is as follows:

- How the settings are not self-incriminating rights (the right of non-selfincrimination) within the law.

- How is the existence of civil rights and the crown witnesses.

\section{Research method}

This prescriptive and descriptive study employs the normative legal approach and qualitative analysis. 


\section{Result and discussion}

\subsection{No self-incriminating rights (the right of non-self incrimination)}

Under the legal doctrine a defendant cannot be put forward as a witness in the same case or other cases that contain the same indictment with him against the other defendants called crown witnesses. This is based on a principle in criminal procedural law that a defendant cannot be sworn because it is not justified by the compulsion towards self-defendant to incriminate himself or non-self-incrimination. In line with the description above, Article 14 paragraph (3) letter g of the ICCPR, states that "everyone has the right to security; not to be compelled to testify against himself, or was forced to admit his mistake. Right not to be put forward as a witness under oath was part of human rights and should be upheld in a legal state of Indonesia" (Sulistio, 2004).

It must be admitted that the witnesses should be protected and his rights secured in a criminal case: first, items owned by a witness to incriminate himself, but as a witness he has no right to refuse; second, given the witness testimony would incriminate the defendant who is a partner in the crime (splitting van zaaken made by the prosecutors who have difficulty obtaining evidence other than the defendant's own testimony). This is closely related to human rights, primarily the right of non-self-incrimination. Furthermore, in article 153 Hukum Acara Pidana (Indonesian Criminal Procedure Code), paragraph 2, part b states that the judge must keep the defendanst from the questions that can lead them not answering the questions freely. Questions that lead tends to approval by the witness or defendant. Article 52 Hukum Acara Pidana (Indonesian Criminal Procedure Code) and Article 153 paragraph (2) letter b of the Hukum Acara Pidana (Indonesian Criminal Procedure Code) and Article 117 paragraph (1) Hukum Acara Pidana (Indonesian Criminal Procedure Code) can be associated with the universal principle of non-self-incrimination of the defendant (defendant's right to not incriminate oneself), as reflected by the indirect and implicit nature of Article 66 Hukum Acara Pidana (Indonesian Criminal Procedure Code)(the suspect or the accused does not bear the burden of proving) and Article 189 paragraph (3) Hukum Acara Pidana (Indonesian Criminal Procedure Code)(defendant's testimony can only be used against himself/herself).

In the case of self-defense by the defendant and he was given the right to deny all the charges, has denied all the witnesses, and the right to lie even for the sake of himself. The Criminal Procedure Code does not expressly prohibit the filing of the crown by the prosecution witnesses in order to prove the charges. The doctrine or teaching of law is prohibited because it violates human rights. While jurisprudence should be used where appropriate with the values of living in a society of law, judges should not be bound by the jurisprudence, because Indonesia does not adopt the principle of the state "the binding force of precedent," and so is free to choose between leaving the jurisprudence to use it in a similar criminal case and obtain the prior decision. The filing of a crown witness in the trial as if it had become rule of law and fact in criminal procedure has been generally accepted. Then, an unjust law becomes a man-made rule that does not match the moral law or the law of God. An unjust law is a set of rules that are inconsistent with the moral law. Thomas Aquinas states, that an unjust law is the law of human creation that is not rooted in eternal law or natural law. Every law that undermines human dignity is not fair. St. Augustine called said "an unjust law is not a law at all" (Wardaya, et al., 2004).

\subsection{Existence and protection of rights of crown witness}

Explanation in the Hukum Acara Pidana (Indonesian Criminal Procedure Code) can be found in 10 principles governing the protection of the Hukum Acara Pidana (Indonesian Criminal Procedure Code) against the "dignity of human dignity," namely, (1) equal 
Proceedings of MICoMS 2017

\section{2}

treatment before the law, without distinction; (2) the arrest, detention, searches, and seizures must be based on written orders; (3) presumption of innocence; (4) the right to receive compensation and rehabilitation; (5) judiciary that is free and done quickly, simple, and lowcost and free, fair, and impartial; (6) the right to obtain legal aid; (7) to a suspect, since the time of the arrest and or detention in addition shall be notified of the charges and the legal basis for what is charged to him, it also shall be notified of their rights including the right to call and ask for the help of legal counsel; (8) rights of the defendant's presence before the court; (9) courts open to the public; (10) obligation to oversee the implementation of court rulings (Soerodibroto, 2004).

The ten principles that need further development and offer guidance for the implementation of the Hukum Acara Pidana (Indonesian Criminal Procedure Code) which really pay attention to and protect Human Rights. Then, on the principle of "justice that is free and is quick and simple," it contains two principles, namely (Rukmini, 2003), (1) judiciary that is free from the influence of any man; (2) the way the criminal justice process must be fast and simple. Freedom of justice is the central point of the concept of state law that adopts the rule of law, where the law enforced is not partial (Komnas HAM, 2002). Free trial does not justify that a person has been "found guilty" before there is strong evidence to prove it; it will not allow the existence of "show trials" that the defendant was not given a proper opportunity to defend himself or herself and people can already guess that would incriminate the defendant judge's decision regardless of evidence or defense. This is a must if the criminal justice process should realize the existence of a "truth of the material" in accordance with the purpose of the judicial process, which is fair and correct and not an engineer in the judicial process or the existence of judicial mafia.

Article 27 paragraph (1) of the Constitution of 1945 states that "all citizens have an equal position in the law and government, and shall uphold the law and government with no exception." Based on the above statement, a fundamental legal principle is the principle of equality in law or is known by the term "equality before the law." Then the first paragraph of Article 28 (5) states that “. . . to uphold and protect human rights in accordance with the principles of a democratic constitutional state, the implementation of human rights is guaranteed, regulated, and set forth in legislation." Furthermore, in international documents (UDHR), the principle of equality in Article 6 and Article 7 states that "everyone has the rights to recognition everywhere as a person before the law". "Everyone is entitled to recognition as a person before the law where he belongs" (Article 6). Article 7 affirms that "all are equal before the law and are entitled without any discrimination to equal protection of the law." All the same ahead of the law and entitled to the same legal protection against discrimination of any kind) (Komnas HAM, 2002).

In Article 1 paragraph (1) of the Law of the Republic of Indonesia Number 39 Year 1999 on Human Rights states that, "human rights are a set of rights attached to the nature and existence of human beings and God Almighty is His grace that must be respected, upheld and protected by the state, law, government and everyone for the respect and protection of human dignity." Based on prima facie principles, the obligation by a crown witness testifies must be carried out, the witness shall declare the right of what he heard, he saw and experienced but in certain special situations can be defeated by a stronger obligation. That means he may be justified to violate the obligations of honesty (truth) by lying to protect himself or his family from the threat of criminal liability. Burdening a person beyond his ability also includes acts that transcend borders, and this is characteristic of human rights abuses. Ignoring the balance (the rights, obligations, and interests of individuals with common interests) not only results in disturbing the rights of a person but also destabilizes morals and justice, which in turn can lead to anarchy (Lopa, 2001). 
From the above description, if associated with the filing by the prosecutor's witnesses crown/public prosecutor in a criminal case is proof of violation of human rights. This is in line with Supreme Court Decision No. 1174 and No. K/Pid/1994. 1592 Marsinah K/Pid/1994 in a murder case. The legal considerations are as follows: Judex Facti means incorrectly applied the evidence of law, where there are witnesses who are defendants in a lawsuit with the same charges broken down is contrary to the Criminal Procedural Law that upholds human rights and anyway the defendant had pulled out in front of his statement investigator and the revocation is justified because of the physical and psychological pressures can be proved true ... (Varia, 1995). [NS5]Steps taken by the Supreme Court in judging the case should be in accordance with the words of Roscoe Pound (1996) that the judges' decision must be based on three steps: (1) finding the law, i.e., rules which specify what can or cannot be applied between many existing rules designated by the way of the legal system; (2) interpreting the rules specified, to determine the meaning as to when it was formed and the rules regarding the question of his/her horizon; (3) applying to the case faced with rules what was discovered and interpreted. This is in accordance with the opinion of I. H. Hymans, a follower of the flow Soziologische Rechtsschule, which states that only the judge's decision is in accordance with the legal awareness and legal needs of the community residents who are "law within the meaning of truth" (het recht der werkelijkheid) (Ali, 2002).

Then, with the Supreme Court's decision to not waive it, then if in a criminal case there is no longer material in addition to crown witness as a means of proof, so to ensure the emergence of legal certainty and maintain public order, the crown witness can be applied with all its consequences. However, the use of crown witnesses is better avoided, but when it is asked the application of legal certainty can be applied to the crown witness respecting the basic rights of the crown witness.

To ensure that human rights violations, it is necessary for witness to be given a peaceful place in the process of proving a criminal case. In one case a suspect is Noyoan, Police Inspector, has determined to not be suspect, but given the status as a crown witness (Kroon getuige) from Schmindt and Jungslaeger suspect who was on trial at the Special Court in Jakarta. This was done solely to better ensure success in the proof than when the witness Noyoan be a suspect. Such efforts were carried out with the consideration of public interest, namely to eliminate the movement of Armed Forces of the Messiah who would undermine the existence of the Republic of Indonesia (Homeland).

To understand the efforts made by the Attorney General in the case of subversion, as mentioned above, should not only for this type of case was all that apply. To present this in matters involving public interest or which took effect to the loss of State and society very much like a case of gross human rights violations and abuse of state finance (corruption), the crown witness should be freed from the shackles of law and the attorney or prosecutor must utilize this witness.

\section{Conclusion}

The role of the crown witness is necessary especially in cases that are very difficult, even almost impossible to get witnesses because of the strength of the perpetrators of crime in maintaining confidentiality. However, theoretically, the consequences will experience psychological pressure, so the statement can be questionable and not objective, so the statement could not be trusted.

The existence and protection of the rights of the crown witness in the proof of a criminal case is against the Hukum Acara Pidana (Indonesian Criminal Procedure Code) which upholds human rights when the testimony is given under oath. In order not to interpret too much on the position and the presence of a crown witness in a criminal case process, which 
Proceedings of ultimately does not achieve the objectives of the law and truth, the Supreme Court of the MICoMS 2017 Republic of Indonesia needs to immediately determine a regulation policy or issue a Supreme Court circular.

\section{References}

Ali, A. (2002). Menguak Tabir Hukum: Suatu Kajian Filosofis dan Sosiologis (2nd ed.). Toko Gunung Agung, Jakarta.

Komisi Nasional Hak Asasi Manusia. (2002). Pendidikan Hak Asasi Manusia Bagi Rohaniwan. Komnas HAM, Jakarta.

Lopa, B.. (2001). Kejahatan Korupsi dan Penegakan Hukum. Buku Kompas, Jakarta.

Mulyadi, L. (2003). KapitaSelektaHukumPidana, Kriminologi dan Victimology Djambatan: Jakarta.

Pound, R. (1996). Pengantar Filsafat Hukum. Penterjemah, Mohamad Radjab, Cet. Kelima, Bharatara Niaga Media, Jakarta.

Rukmini, M. (2003). "Perlindungan HAM Melalui Asas Praduga Tidak Bersalah dan Asas Persamaan Kedudukan Dalam Hukum Pada Sistem Peradilan Pidana Indonesia”. Alumni, Bandung.

Soerodibroto, R.S. (2004). KUHP dan KUHAP (5th ed., Cet.10). RajaGrafindo Persada, Jakarta.

Sulistio. (2004). Perjuangan Menemukan Hukum. Gajah Mada University Press, Yogyakarta.

Varia Peradilan. (1995, Agustus dan September). Majalah Hukum Tahun X No. 119 dan 120.

Wardaya, B.T. (2004). "Pembebasan Manusia: Sebuah Refleksi Multidimensional". Buku Baik, Yogyakarta.

\section{Corresponding author}

Zulfan can be contacted at zulfan@unimal.ac.id 